10.15290/cnisk.2019.02.07.03

\author{
DR EDYTA CHROBACZYŃSKA-PLUCIŃSKA \\ orcid.org/0000-0003-3351-860X \\ Uniwersytet Pedagogiczny im. KEN w Krakowie
}

\title{
Posłanki na Sejm PRL II kadencji (1957-1961). Cechy socjopolityczne i aktywność poselska
}

\begin{abstract}
Streszczenie
Autorka koncentruje się na analizie cech socjopolitycznych i kierunkach aktywności parlamentarnej posłanek zasiadajacych w Sejmie PRL II kadencji (1957-1961). Z jednej strony celem badań jest charakterystyka posłanek $z$ uwzględnieniem takich kryteriów, jak wiek, wykształcenie, zawód, orientacja polityczna, a także przynależność do klubów i kół poselskich. $Z$ drugiej zaś przeanalizowano obszary aktywności w wybranych komisjach parlamentarnych, składane interpelacje oraz zagadnienia poruszane w przemówieniach sejmowych. Autorka chciałaby częściowo wypełnić lukę w najnowszych badaniach nad historią kobiet w okresie PRL. W sferze metodologii odwołano się do krytycznej analizy treści. Podstawę źródłową stanowią biuletyny prasowe, sprawozdania stenograficzne z posiedzeń sejmu oraz dokumenty zgromadzone w archiwach.
\end{abstract}

Słowa kluczowe: historia kobiet, parlamentaryzm, sejm PRL, posłanki 


\title{
THE SOCIO-POLITICAL CHARACTERISTICS AND PARLIAMENTARY ACTIVITY OF FEMALE MPS IN THE POLISH PEOPLE'S REPUBLIC SEJM OF THE SECOND TERM (1957-1961)
}

\begin{abstract}
The author focuses on analysing socio-political characteristics and trends in the parliamentary activity of female MPs serving in the Polish People's Republic Sejm of the second mandate (1957-1961). On the one hand, her research aims at characterising those MPs taking into account such criteria as age, education, profession, political orientation as well as membership in political groups and circles. The other aspect of the research concerns the areas of their activity in selected parliamentary committees, the parliamentary questions they submitted and the subjects raised by them in parliamentary speeches. The author seeks, if only partially, to fill the gap in most recent studies of women's history in the period of the Polish People's Republic (PPR). In terms of methodology, critical content analysis is used. The source base is press bulletins, stenographic transcripts of Sejm sittings and archive documents.
\end{abstract}

Keywords: women's history, parliamentarism, Sejm of the Polish People's Republic, female MPs

\section{Wstęp}

Udział kobiet w polityce to problem wieloaspektowy. Zarówno w perspektywie historycznej, jak i obecnie ich stosunkowo niskiej aktywności nie różnicuje przyjęcie antydyskryminacyjnych rozwiąań na poziomie prawodawczym. Faktyczne nierówności nadal utrzymuja się w wymiarze praktycznym. Wpływ na to maja stopień świadomości społecznej w zakresie korzystania z przysługujących praw, poziom eliminacji ukrytych barier, a także, a może przede wszystkim, brak postępującej ewolucji o znaczeniu kulturowym.

Po II wojnie światowej wraz z lansowanym przez władze hasłem równouprawnienia płci wprowadzano przepisy mające ułatwić kobietom aktywność w przestrzeni publicznej. Charakter ustanowionego po 1945 r. niedemokratycznego ustroju politycznego paradoksalnie wyzwolił emancypację kobiet, nawet jeśli była ona odgórnie sterowana. Na utrwalanie tego hasła wpływ miała realizowana linia polityczna PPR, a później PZPR, która oficjalnie je promowała, przynajmniej do 1956 r. Docenić należy 
wysiłek ówczesnych działaczek komunistycznych, które po wyzwoleniu jako parlamentarzystki czynnie uczestniczyły w pracach najpierw Sejmu Ustawodawczego, a potem Sejmu I kadencji PRL, podejmujac działania na rzecz przyjęcia określonych rozwiązań legislacyjnych, które hasło równouprawnienia miały uczynić praktycznie użytecznym ${ }^{1}$.

Warto zwrócić też uwagę na historyczny kontekst wyborów parlamentarnych z 1957 r. Druga kadencja sejmu przypadała w szczególnym okresie przełomu. Śmierć Stalina i wystapienie Chruszczowa stały się wstępem do polskiego Października 1956 r., kończącego faktycznie okres nazywany w historiografii mianem stalinizacji kraju (1944/45-1956) ${ }^{2}$. Wybory, które odbyły się w 1957 r., ale przede wszystkim atmosfera im towarzysząca, dawały nadzieję ówczesnemu społeczeństwu na istotne zmiany jakościowe w zakresie charakteru sprawowanej władzy i przesunięcia punktu ciężkości na demokratyczniejsze i bardziej autonomiczne pozycje. Znalazło to swoje odbicie w ordynacji wyborczej zarówno w procedurze obsadzania list wyborczych, jak i samego sposobu głosowania. Parlament w większym stopniu miał uosabiać preferencje społeczne ${ }^{3}$. Częściowo klimat ten uwidocznił się także w praktyce działania Sejmu II kadencji. Przyjęto m.in. formalne regulacje dotyczace funkcjonowania klubów i kół poselskich. Zwłaszcza ta druga forma dawała możliwość organizowania się posłom spoza klucza oficjalnych partii. Do sejmu dostali się kandydaci bezpartyjni, w tym przedstawiciele środowisk katolickich, którzy utworzyli koło poselskie Znak .

$Z$ jednej strony celem prowadzonych badań jest charakterystyka posłanek zasiadających w sejmie w latach 1957-1961, uwzględniajaca

\footnotetext{
1 Szerzej: Edyta Chrobaczyńska-Plucińska, „Równouprawnienie płci w debacie parlamentarnej Sejmu Ustawodawczego 1947-1952. Zarys problemu", w: Julita Czernecka, Krystyna Dzwonkowska-Godula (red.), Kobiecość i męskość w publicznym dyskursie, społecznych praktykach $i$ indywidualnych doświadczeniach, Seria wyd. Acta Universitatis Lodziensis. Folia Sociologica, nr 70, (Łódź : Wydawnictwo Uniwersytetu Łódzkiego, 2019), 17-38.

2 Za Krystyna Kersten - stalinizm to „historycznie ukształtowany, system komunistycznego totalitaryzmu". Krystyna Kersten, Pisma rozproszone, wybór i przygot. do druku Tomasz Szarota, Dariusz Libionka, (Torun : Wydawnictwo Adam Marszałek, 2005), 388. 3 Piotr Ossowski, Czerwona Michalina. Michalina Tatarkówna-Majkowska. Przadkadziałaczka - łodzianka, (Łódź : Księży Młyn, 2017), 129-137; Janina Zakrzewska, Tadeusz Mołdawa, Andrzej Ajnenkiel (red.), Historia sejmu polskiego, t. 3: Polska Ludowa, (Warszawa : Państwowe Wydawnictwo Naukowe, 1989), 163.

4 Juliusz Bardach (red.), Dzieje sejmu polskiego, (Warszawa: Wydawnictwo Sejmowe, 2011), 257-259; Janina Zakrzewska, Tadeusz Mołdawa, Andrzej Ajnenkiel (red.), Historia sejmu polskiego, 150-152, 168-170.
} 
takie kryteria socjopolityczne, jak wiek, wykształcenie, zawód, uczestnictwo w poszczególnych komisjach, a także przynależność do klubów i kół parlamentarnych. $Z$ drugiej zaś analiza ich aktywności podejmowanych w komisjach parlamentarnych, jak również zagadnień, które poruszały w przemówieniach sejmowych, także w kontekście tzw. problematyki kobiecej. Analiza ma wykazać, czy II kadencja sejmu różniła się od wcześniejszych w zakresie liczby i charakteru zasiadajacych w nim kobiet oraz czy spectrum ich zainteresowań ewoluowało, ulegając rozszerzeniu, czy też było kontynuacją wcześniejszych aktywności5 ${ }^{5}$.

\section{Stan badań, materiały i metody}

Współcześnie uwaga badaczy analizujących problematykę udziału kobiet w polityce koncentruje się na dwóch zasadniczych okresach - historycznym, o charakterze rozproszonym, i współczesnym. $Z$ jednej strony badania obejmuja przełom XIX i XX w., uwzględniając czas zaborów i Polskę międzywojnia, $z$ drugiej zaś okres transformacji ustrojowej otworzył nowe pola do dyskusji dotyczącej skali i skuteczności aktywności kobiet w szeroko rozumianej polityce po 1989 r. Stosunkowo nieliczne grono badaczy koncentruje się na analizach stopnia i charakteru aktywnej sprawczości kobiet w latach Polskiej Rzeczypospolitej Ludowej. Jeszcze mniej liczna jest grupa tych, która podważa powszechnie przyjmowaną tezę, że istniejący ówcześnie system ustrojowy całkowicie wykluczył autentyczną możliwość realizacji postulatu emancypacji kobiet $^{6}$. Częśsiowo zagadnienie to było przedmiotem badań prowadzonych także jeszcze przed 1989 r. ${ }^{7}$ Współcześnie problematyką rzeczywistego

\footnotetext{
5 Artykuł przygotowany w ramach realizacji projektu badawczego $\mathrm{nr}$ 2018/02/X/ HS3/00650 finansowanego ze środków Narodowego Centrum Nauki pt. „Analiza aktywności politycznej posłanek w organach ustawodawczych PRL 1944/45-1989”.

${ }_{6} \quad \mathrm{Z}$ uwagi na rygory formalne objętości artykułu wskazano wybrana bibliografię tylko w ostatnim przypadku badaczy. Małgorzata Fidelis, Kobiety, komunizm $i$ industrializacja w powojennej Polsce, (Warszawa : Wydawnictwo W.A.B, 2015); Agnieszka Mrozik, „Wywołać z milczenia. Historia kobiet w PRL-u - kobiety w historii PRL-u”, Teksty Drugie : teoria literatury, krytyka, interpretacja, nr 4, 2011, 112-119; Eadem, „Poza nawiasem historii (kobiet), czyli po co nam dziś komunistki”, Wakat On-line, nr 3, 2014; Magdalena Grabowska, Zerwana genealogia. Działalność społeczna i polityczna kobiet po 1945 roku a współczesny polski ruch kobiecy, (Warszawa : Wydawnictwo Naukowe Scholar, 2018).

7 Renata Siemieńska, Płeć, zawód, polityka. Kobiety w życiu publicznym w Polsce, (Warszawa : Uniwersytet Warszawski, Instytut Socjologii, 1990).
} 
władczego udziału i roli kobiet w aparacie partyjnym po 1944/1945 r. zajmują się Natalia Jarska ${ }^{8}$ oraz Mirosław Szumiło ${ }^{9}$.

W polskiej literaturze brakuje natomiast publikacji analizujacych obecność i aktywność kobiet w polskich organach ustawodawczych w latach 1944/45-1989 ${ }^{10}$. Wśród przyczyn pomijania tego okresu we współczesnych badaniach naukowych najczęściej wymienia się pogląd o fasadowym charakterze samej instytucji sejmu. Oczywiście nie można negować badań, które potwierdzają słuszność tezy, że zasadnicze, władcze decyzje polityczne, także w zakresie działalności sejmu, podejmowane były przez centralne organy partyjne i stanowiły pochodna zawłaszczenia państwa i społeczeństwa przez monopartię. Otwarte pozostaje jednak pytanie o rolę parlamentarzystek w projektowaniu prawa oraz o charakter ich aktywności.

W sferze metodologii autorka odwołała się do metody krytycznej analizy treści i metody porównawczej. W warstwie źródłowej na potrzeby niniejszego artykułu zostały przeanalizowane sprawozdania stenograficzne z posiedzeń Sejmu PRL II kadencji oraz biuletyny prasowe i sprawozdania wybranych komisji parlamentarnych. Fragmentarycznie wykorzystano również archiwalia zgromadzone w zbiorach Archiwum Akt Nowych i Archiwum Sejmu.

8 Natalia Jarska, „Kobiety w PZPR 1948-1956. Paradoksy mobilizacji politycznej kobiet w stalinizmie”, w: Ewa Chabros, Agnieszka Klarman (red.), Kobiety „na zakręcie” 1933-1989, (Wrocław : Instytut Pamięci Narodowej - Komisja Ścigania Zbrodni przeciwko Narodowi Polskiemu, 2014), 33-49; Natalia Jarska, Piotr Perkowski, „Droga do władzy? Kobiety w PZPR 1948-1989", Pamięć i Sprawiedliwość, nr 27, 2016, 231-246; Natalia Jarska, „Krótki kurs historii «kobiet». Kobiety w języku partii komunistycznej w Polsce 1945-1989", Polska 1944/45-1989. Studia i Materiały, nr 15, 2017, 241-259.

9 Mirosław Szumiło, „Kadra kierownicza aparatu wykonawczego KC PPR-PZPR w latach 1944-1956", w: Artur Górak, Ireneusz Adam Łuć, Dariusz Magier (red.), Dzieje biurokracji na ziemiach polskich, t. 1, (Radzyń Podlaski : Radzyńskie Stowarzyszenie Inicjatyw Lokalnych : Radzyńskie Towarzystwo Naukowe [Libra], 2008), 581-595; Idem, „I sekretarze Komitetów Wojewódzkich PPR (1944-1948) - portret zbiorowy", Dzieje Najnowsze, z. 4, 2013, 43-59; Idem, „Kobiety w kadrze kierowniczej centralnego aparatu partyjnego PPR i PZPR", Teka Komisji Historycznej, XIII, 2016, 196-215.

10 Częściowo do tej tematyki odwolują się: Małgorzata Fuszara, Kobiety w polityce, (Warszawa : Wydawnictwo Trio, 2006), 88-90; Małgorzata Niewiadomska-Cudak, Kobiety $w$ polskich organach kolegialnych $w$ latach 1919-2011, (Torun : Wydawnictwo Mado, 2013), 124-137; Renata Siemieńska, Płeć, zawód, polityka. 


\section{Posłanki - cechy socjopolityczne}

W badanym okresie w Sejmie II kadencji zasiadało 19 kobiet. Zarówno wobec wcześniejszych, jak i późniejszych elekcji, przypadających na lata 1944/45-1989, była to grupa niewielka.

$\mathrm{Na}$ ogólną liczbę 459 ówczesnych parlamentarzystów ${ }^{11}$ kobiety stanowiły zatem jedynie 4,1\%. Dla porównania - w KRN i w Sejmie Ustawodawczym odsetek ten był większy i stanowil odpowiednio $7 \%{ }^{12}$ i $5,6 \%{ }^{13}$. W pozostałych kadencjach $z$ lat 1952-1989 (I-IX) wahał się między $12 \%$ a $23 \%{ }^{14}$. Znamienny jest fakt, że kiedy sejm ponownie miał się stać organem autentycznej pracy, spadła jednocześnie liczba zasiadających w nim kobiet. Zbiegło się to także $z$ decyzją władz partii o stopniowym odchodzeniu od dotychczas lansowanego, przynajmniej formalnie, poparcia dla idei emancypacji kobiet. Propagowany do niedawna wzór kobiety aktywnej zaczął ponownie ewoluować w kierunku tradycyjno-patriarchalnym, $z$ naciskiem na rolę kobiety jako matki. $Z$ ław parlamentarnych zniknęły, tak liczne w I kadencji, posłanki reprezentujące robotnice i chłopki ${ }^{15}$. Kim zatem były parlamentarzystki zasiadające w II kadencji Sejmu PRL?

Analiza uczestnictwa w poszczególnych kadencjach wskazuje, że nie wszystkie posłanki debiutowały w nowej roli. Spośród dziewiętnastu, które weszły do sejmu w 1957 r., w poprzednich kadencjach zasiadało siedem: Helena Jaworska, Eugenia Krassowska-Jodłowska, Alicja Musiałowa, Michalina Tatarkówna-Majkowska, Jadwiga Prawdzicowa,

11 Tadeusz Mołdawa, Sejm Polskiej Rzeczpospolitej [!] Ludowej, (Warszawa : Krajowa Agencja Wydawnicza, 1987), 146.

12 „Sprawozdania stenograficzne - KRN”, pos. 9, 29.12.1945-3.01.1946, 273-274; Urszula Ćwik, „Wybory parlamentarne i wybory do rad narodowych w Polskiej Rzeczpospolitej Ludowej na łamach "Kobiety i Życia" (do 1989 roku)", w: Małgorzata Dajnowicz, Adam Miodowski (red.), Polityka i politycy w prasie XX i XXI wieku, (Białystok : Wydawnictwo Humanica, 2016), 331.

13 Małgorzata Niewiadomska-Cudak, Kobiety w polskich organach kolegialnych, 129.

14 Renata Siemieńska, Płeć, zawód, polityka, 180-181.

15 Zasadniczo słuszna wydaje się teza, że udział kobiet w parlamencie spada, gdy parlament uzyskuje rzeczywista władzę. Potwierdzają to wybory parlamentarne z 1989 i 1991 r. Szerzej: Małgorzata Fuszara, Kobiety w polityce, 89-90. Warto jednak zauważyć, że w okresie PRL w Sejmie VIII kadencji (1980-1985) odsetek kobiet był największy (106 posłanek) i stanowił 23\% ogólnej liczby posłów. Jednocześnie ówczesny parlament, z całym jego kontekstem polityczno-społecznym, na tle innych $z$ tego okresu traktowany był jako „autentyczny reprezentant społeczeństwa”. Najwięcej interpelacji zgłoszono właśnie w II i VIII kadencji sejmu, w tej ostatniej często sięgano również do instytucji konsultacji społecznych. 
Anna Tarniewicz oraz Zofia Wasilkowska. Bardzo liczna, bo dwunastoosobowa, była natomiast grupa kobiet, które w sejmie znalazły się po raz pierwszy: Irena Białówna, Irena Jankiewicz, Zuzanna Josińska-Kurjańska, Władysława Krzeszowska (Grzesiak), Elżbieta Liszka, Maria Maniakówna, Wanda Pieniężna oraz Maria Regentowa. Dla każdej z nich było to pierwsze i zarazem ostatnie spotkanie $z$ sejmem. Były jednak też takie, które po debiucie w Sejmie II kadencji dalej sprawowały mandat poselski, zdobywajac go w kolejnych wyborach. Do tego grona należały Janina Doliwa-Taborska, Magdalena Dubiel, Balbina Semczuk i Zofia Stypułkowska.

$\mathrm{Na}$ podstawie analizowanych danych biograficznych ${ }^{16}$ można skonstatować, że dwie najmłodsze posłanki, jednocześnie debiutantki, w momencie objęcia sprawowanej funkcji miały po 26 lat. Były to Josińska-Kurjańska i Krzeszowska. Stosunkowo nieliczna, bo jedynie trzy posłanki, była także grupa kobiet, które nie przekroczyły 40. roku życia. W tej roli po raz pierwszy znalazły się Regentowa i Stypułkowska, ale również Jaworska, doświadczona parlamentarzystka, która mandat, jeszcze do KRN, uzyskała w wieku zaledwie 21 lat. Z kolei 50- i 60-latek było łącznie pięć: trzy najstarsze to $z$ jednej strony bezpartyjne debiutantki, które zasiadały tylko w II kadencji - Liszka i Pieniężna, z drugiej zaś przedstawicielka SD - Prawdzicowa, która była posłanka w Sejmie I kadencji. Najliczniejszą grupę stanowiły parlamentarzystki miedzy 41 . a 50. rokiem życia, co stanowi naturalna prawidłowość, wynikajaca ze zwiększonej aktywności w tym okresie życia.

Tabela 1. Wiek

\begin{tabular}{|c|c|c|c|c|c|c|}
\hline Wiek & Do 30 lat & 31-40 lat & 41-50 lat & 51-60 lat & $\begin{array}{c}\text { Powyżej } \\
\text { 60 lat }\end{array}$ & Razem \\
\hline $\begin{array}{l}\text { Sejm II } \\
\text { kadencji }\end{array}$ & 2 & 3 & 9 & 2 & 3 & 19 \\
\hline
\end{tabular}

Źródło: obliczenia własne.

${ }_{16}$ Archiwum Akt Nowych, Archiwum Sejmu, Biblioteka Sejmowa. 
Tabela 2. Wykształcenie

\begin{tabular}{|c|c|c|c|c|c|}
\hline \multirow{2}{*}{ Kadencja } & \multirow{2}{*}{$\begin{array}{c}\text { Liczba } \\
\text { posłanek }\end{array}$} & \multicolumn{4}{|c|}{ Liczba posłanek w zależności od wykształcenia } \\
\hline & & wyższe & średnie & podstawowe & brak danych \\
\hline KRN & 35 & $\begin{array}{l}21(60 \%) \\
\text { w tym } 2 \\
\text { niepełne }\end{array}$ & $\begin{array}{l}13(37 \%) \\
\text { w tym } 1 \\
\text { niepełne }\end{array}$ & $1(3 \%)$ & 0 \\
\hline $\begin{array}{l}\text { Sejm } \\
\text { Ustawodawczy } \\
1947-1952\end{array}$ & 26 & $\begin{array}{l}13(50 \%) \\
\text { w tym } 2 \\
\text { niepełne }\end{array}$ & $\begin{array}{l}11(42 \%) \\
\text { w tym } 1 \\
\text { niepełne }\end{array}$ & $2(8 \%)$ & 0 \\
\hline $\begin{array}{l}\text { Sejm } \\
\text { I kadencji } \\
1952-1956\end{array}$ & 75 & $\begin{array}{l}16(21 \%) \\
\text { w tym } 2 \\
\text { niepełne }\end{array}$ & $\begin{array}{l}18(24 \%) \\
\text { w tym } 4 \\
\text { niepełne }\end{array}$ & $41(55 \%)$ & 0 \\
\hline $\begin{array}{l}\text { Sejm II } \\
\text { kadencji } \\
1957-1961\end{array}$ & 19 & $9^{a}(47 \%)$ & $7^{\mathrm{b}}(37 \%)$ & $2(11 \%)^{\mathrm{c}}$ & $1(1 \%)$ \\
\hline Razem & 155 & 59 & 49 & 46 & 1 \\
\hline
\end{tabular}

Źródło: obliczenia własne.

${ }^{a}$ Lekarka (2), filolożka, historyczka, prawniczka (4), nauczycielka.

${ }^{\mathrm{b}}$ Nauczycielka (3), dziennikarka (2), technik przędzalnik (2).

c Tkaczka i rolniczka.

Analizując poziom wykształcenia posłanek Sejmu II kadencji, należy zauważyć, że ich zdecydowana większość (84\%) miała wykształcenie wyższe i średnie. Te $z$ wykształceniem podstawowym stanowiły jedynie $11 \%$ ogółu wszystkich kobiet ${ }^{17}$. Podobna prawidłowość zachodziła w KRN - odpowiednio 97\% i 3\% oraz w Sejmie Ustawodawczym - 92\% i 8\%. $\mathrm{Na}$ tym tle zdecydowanie odmiennie sytuuje się Sejm I kadencji. W tym przypadku wykształcenie wyższe i średnie miało tylko $45 \%$ posłanek, podstawowe natomiast aż $55 \%{ }^{18}$.

$\mathrm{Na}$ fali haseł demokratyzacji życia nastapił powrót do forsowania kandydatek wykształconych, często bezpartyjnych działaczek, znanych i docenianych w regionie, jak np. Białówna czy Prawdzicowa. Do sejmu trafily lekarki, nauczycielki, prawniczki, a zarazem niewielka reprezentacja robotnic i rolniczek, które w I kadencji stanowiły większość, co było

17 Na tym etapie badań danych nie udało się ustalić jedynie w przypadku posłanki Liszki.

18 Szerzej: Edyta Chrobaczyńska-Plucińska, „Posłanki w organach ustawodawczych 1944/45-1956. Cechy socjopolityczne i aktywność poselska”, w: Łukasz Tomczak, Katarzyna Zawadzka (red.), Kobiety w wyborach. Wybory kobiet, [w druku]. 
najprawdopodobniej związane $z$ lansowaną ówcześnie linią polityczną partii w zakresie realizowania zasady równouprawnienia płci.

Najwięcej posłanek reprezentowało klub poselski PZPR. Należały do niego Doliwa-Taborska, Jaworska, Krzeszowska (Grzesiak), Musiałowa, Semczuk, Tatarkówna-Majkowska oraz Wasilkowska. Równie silną grupę, na co należy zwrócić uwagę, stanowiły posłanki bezpartyjne: Białówna, Dubiel, Jankiewicz, Josińska-Kurjańska, Liszka oraz Pieniężna reprezentujacca koło poselskie Znak. $Z$ ramienia SD w sejmie zasiadały Krassowska-Jodłowska, Prawdzicowa, Regentowa oraz Stypułkowska, klub ZSL reprezentowały zaś Maniakówna i Tarniewicz.

\section{Aktywność parlamentarna}

Wraz ze wzrostem znaczenia sejmu zwiększyła się także liczba i rola komisji parlamentarnych. Powołano ich 24 - 19 stałych i 5 nadzwyczajnych. Podobnie jak w poprzednich latach, posłanki licznie zasiadały w kilku komisjach. Sześć z nich zasiadało w Komisji Zdrowia i Kultury Fizycznej (KZiKF): Białówna, Doliwa-Taborska, Jankiewicz, Maniak, Musiałowa, Tarniewicz. Pięć było w Komisji Pracy i Spraw Socjalnych (KPiSS): Białówna, Josińska-Kurjańska, Musiałowa, Pieniężna oraz Prawdzicowa ${ }^{19}$. Cztery w Komisji Oświaty i Nauki (KOiN): Dubiel, Pieniężna, Prawdzicowa i Semczuk. Po trzy posłanki zasiadały w Komisji Spraw Zagranicznych (KSZ) - Krassowska-Jodłowska, Musiałowa, Wasilkowska; Kultury i Sztuki (KiS) - Jaworska, Maniak, Regentowa; Komisji Spraw Wewnętrznych (KSW) - Jaworska, Stypułkowska, Wasilkowska oraz Komisji Regulaminowej (KR) - Prawdzicowa, Tatarkówna-Majkowska, Wasilkowska. Po dwie natomiast weszły w skład Komisji Przemysłu Lekkiego Rzemiosła i Spółdzielczości Pracy (KPLRiSP) - Tatarkówna-Majkowska i Krzeszowska (Grzesiak), która jednocześnie była pierwszą kobieta na stanowisku przewodniczącej; Komisji Wymiaru Sprawiedliwości (KWS) - Regentowa i Wasilkowska oraz Komisji Nadzwyczajnej Ziem Zachodnich (KNZZ) - Liszka i Pieniężna. W pozostałych reprezentacja kobiet liczyła po jednej posłance. Były to: Komisja Budownictwa i Gospodarki Komunalnej (KBiGK) - Stypułkowska; Komisja Mandatowa (KM)

19 W 1957 r. chęć współpracy zgłosiła także Elżbieta Liszka, co spotkało się z aprobata komisji. „Sprawozdanie z działalności Komisji Pracy i Spraw Socjalnych Sejmu II kadencji”, (Warszawa : Biuro Sejmu, Wydział Prasowy, 1961), 2. 
- Maniak; Komisja Planu Gospodarczego, Budżetu i Finansów (KPGBiF)

- Tatarkówna-Majkowska oraz dwie komisje nadzwyczajne - do rozpatrzenia projektu ustawy o radach narodowych $z$ posłanką Musiałową i do opracowania projektu ustawy o NIK z Wasilkowska.

Kobiety tradycyjnie były aktywne w Komisji Zdrowia i Kultury Fizycznej. Jako wiceprzewodnicząca w prezydium Komisji zasiadała Maniakówna. Zagadnienia poruszane na jej forum dotyczyły trzech głównych obszarów problemowych: zdrowia, sportu oraz wychowania fizycznego i turystyki. Posiedzenia, na których analizowano problemy służby zdrowia, oscylowały wokół takich zagadnień, jak lecznictwo otwarte i resortowe (zakłady pracy, zwłaszcza górnictwo), uzdrowiska, budownictwo w służbie zdrowia, szkolnictwo medyczne, opieka nad małoletnimi, warunki bhp w zakładach pracy, oświata sanitarna, nowotwory, leki i ich dystrybucja, lecznictwo zakaźne i pediatryczne ${ }^{20}$. Członkowie Komisji procedowali m.in. nad dwoma rzadowymi projektami ustaw - przeciwgruźliczą i o przejściowym trybie nabywania uprawnień pielęgniarki ${ }^{21}$.

Niewątpliwie jednym $z$ ważniejszych aktów normatywnych tej kadencji była przyjęta w kwietniu 1959 r. ustawa o zwalczaniu gruźlicy, której projekt referowała w sejmie Doliwa-Taborska. Ówczesna sytuacja epidemiologiczna w Polsce była najtrudniejsza w całej Europie ${ }^{22}$. Dlatego tak ważny stał się ujęty w formie aktu ustawowego narodowy program do walki z gruźlica. Wprowadzono całkowicie bezpłatne świadczenia, szczepienia i doszczepienia dzieci, zasiłki chorobowe, a także ochronę stosunku pracy ${ }^{23}$. W dyskusji tej aktywny udział brała Prawdzicowa, która już w okresie międzywojennym była związana $z$ Wojewódzkim Towarzystwem Walki z Gruźlica, a po zakończeniu działalności publicznej nadal angażowała się $\mathrm{w}$ walkę $\mathrm{z}$ tą chorobą ${ }^{24}$. Podkreślała, że spośród wszystkich chorób zakaźnych występujących ówcześnie w Polsce największą umie-

\footnotetext{
20 Ibidem, 1-3, 15; Anna Tarniewicz, „Sprawozdania stenograficzne Sejmu II Kadencji” (dalej: SSS II), pos. 20, 26.03.1958, 135-138. Por. także Biuletyn Prasowy Sejmu (dalej: BPS), Komisja Zdrowia i Kultury Fizycznej (dalej: KZiKF), 10.03.1957, 2-9; 15.06.1957, 5-8.

${ }^{21}$ „Sprawozdanie z pracy Komisji Zdrowia i Kultury Fizycznej w okresie II kadencji Sejmu PRL", 16.

22 Tadeusz M. Zielonka, „Epidemiologia gruźlicy w Polsce - implikacje w praktyce lekarza rodzinnego", Forum Medycyny Rodzinnej, t. 10, nr 1, 2016, 26; BPS, KZiKF, 9.04.1959, 1-13.

${ }^{23}$ SSS II, pos. 36, 22.04.1959, 61-69.

24 Ibidem, 76.
} 
ralność generowała właśnie gruźlica ${ }^{25}$. Obie posłanki odwoływały się do dramatycznej sytuacji osób chorych w II $\mathrm{RP}^{26}$. Główny nacisk położony został na profilaktykę. Coraz więcej młodych ludzi pomiędzy 20. a 39. rokiem życia pobierało renty inwalidzkie ${ }^{27}$. Gruźlica stawała się chorobą społeczną i niezbędne stało się kształtowanie w tym zakresie także świadomości obywateli, przede wszystkim na wsi. Posłanki podkreślały też rolę organizacji społecznych, takich jak Liga Kobiet ${ }^{28}$, przy której zarządach planowano organizować stosowne poradnie.

Doliwa referowała w sejmie również projekt ustawy o przejściowym trybie nabywania uprawnień pielęgniarki. Braki w zakresie wykwalifikowanego średniego personelu medycznego oraz rosnąca dysproporcja wobec kadry lekarskiej ${ }^{29}$ były spowodowane konsekwencjami działań wojennych, w tym strat osobowych i likwidacji większości szkół pielęgniarskich, ale także powojennym dynamicznym rozwojem infrastruktury szpitalnej. W 1950 r. wydano dekret zawierajaccy przepisy przejściowe dotyczące uzyskiwania uprawnień w tym zawodzie, rozpoczęto też organizowanie najpierw kursów, a później szkół pomaturalnych i liceów pielęgniarskich. Spora liczba kobiet nie uporzadkowała jednak swoich kwalifikacji zawodowych, a wspomniany dekret stracił ważność, dlatego pilną sprawą stała się potrzeba przyjęcia nowych przepisów ${ }^{30}$.

Z kolei w katalogu zagadnień problemowych, które stały się przedmiotem prac Komisji Pracy i Spraw Socjalnych, znalazły się: polityka zatrudnienia, szkolenie zawodowe młodocianych, renty ${ }^{31}$, walka $z$ alkoholizmem, gospodarowanie funduszem interwencyjnym ${ }^{32}$ i aktywizacja gospodarcza małych miast, pomoc społeczna, bezpieczeństwo i higiena pracy, rehabilitacja inwalidów oraz zatrudnianie kobiet ${ }^{33}$. Dużą

\footnotetext{
25 Ibidem, 74.

26 Jerzy Janiuk, „Gruźlica w okresie Młodej Polski i dwudziestolecia międzywojennego w teorii i praktyce medycznej (cz. 1)", Medycyna Nowożytna, t. 16, z. 1-2, 2010, 41-78.

27 SSS II, pos. 36, 22.04.1959, 75.

28 Ibidem, 77.

29 Maria Maniak, SSS II, pos. 46, 14.06.1960, 100; BPS, KZiKF, 7.05.1960, 1-6.

30 Janina Doliwa-Taborska, Ibidem, 94-98.

31 Elżbieta Liszka podkreślała, że projekt ustawy o rentach i zapatrzeniach dyskryminuje wdowy, zwłaszcza te, które nie pracowały zawodowo. SSS II, pos. 22, 28.03.1958, 19-20.

32 Jadwiga Prawdzicowa, Alicja Musiałowa, BPS, Komisja Pracy i Spraw Socjalnych (dalej: KPiSS), 7.11.1958, 13,15.

33 „Sprawozdanie $z$ działalności Komisji Pracy i Spraw Socjalnych Sejmu II kadencji”, 6.
} 
aktywność w Komisji przejawiała posłanka Prawdzicowa, co zostało nawet zaakcentowane w sprawozdaniu kadencyjnym $z$ prac ${ }^{34}$.

Zdecydowanie priorytetowy charakter miała walka $z$ pijaństwem. $Z$ inicjatywy posłów powołano Komisję Rady Ministrów do Spraw Walki z Alkoholizmem, która zainicjowała dwuletni (1959-1960) program rządowy do walki $z$ tym nałogiem. Inicjatywa projektu ustawy wyszła ze strony rządu, ale przy znaczącym zaangażowaniu ze strony członków Komisji, a także organizacji społecznych - Ligi Kobiet ${ }^{35}$ czy Polskiego Czerwonego Krzyża. Ich przedstawiciele byli obecni na posiedzeniach Komisji zarówno w tej, jak i w innych sprawach dotyczacych pomocy społecznej czy zatrudniania kobiet ${ }^{36}$. Nie brakowało też uwag krytycznych. Dotychczasowe prace w zakresie przeciwdziałania alkoholizmowi posłanka Prawdzicowa określiła jako chaotyczne i nieskuteczne ${ }^{37}$. Głos w sprawie zabierały także Liszka, Musiałowa, Białówna oraz Josińska-Kurjańska ${ }^{38}$. Ostatecznie prace zaowocowały zmianami legislacyjnymi i przyjęciem w grudniu 1959 r. ustawy o zwalczaniu alkoholizmu.

W sprawie zatrudniania kobiet głos zabrały posłanki Musiałowa i Liszka. Zwracały uwage na liczne przypadki zwalniania zwłaszcza tych $z$ wysokimi kwalifikacjami zawodowymi, lecz niemajacymi jednocześnie innych źródeł utrzymania ${ }^{39}$. Tematyka ta wpisywała się w zakres egzekwowania zasady równouprawnienia $\mathrm{płci}^{40} \mathrm{i}$ była obecna także w poprzednich kadencjach sejmu. Kierownictwo partii jednak w coraz mniejszym stopniu identyfikowało się $z$ tym hasłem, co wybrzmiało $\mathrm{w}$ słowach posłanki Josińskej-Kurjańskiej, która wręcz nawoływała $z$ mównicy sejmowej, aby „wspominajac dawne przodownice pracy zawodowej i społecznej, nie stwarzać specjalnego dla nich kultu"41, bo rola biologiczna kobiety jest nie do przecenienia. Oczywiście rozumiała ona wagę osiagnięć, które pozwoliły kobietom wyjść ze sfery prywatnej, dlatego popularyzowała

\footnotetext{
${ }^{34}$ Ibidem, 3. Por. udział w dyskusji na temat ustawy o rentach i zapatrzeniach, o czasie pracy w przemyśle i handlu. Wanda Pieniężna, SSS II, pos. 22, 28.03.1958, 38-42; pos. 25, 1.07.1958, 131-137.

35 Jadwiga Prawdzicowa, BPS, KPiSS, 4.02.1958, 7.

36 Ibidem, 16. Por. także: Irena Białówna, Janina Doliwa-Taborska, BPS, KZiKF, 5.10.1957, 4-6, 10-11.

37 Jadwiga Prawdzicowa, BPS, KPiSS, 16.09.1957, 1-6; 14.11.1957, 2-3.

38 BPS, KPiSS, 18.09.1957, 6-8; 8.11.1958, 9-10; 28.01.1960, 7.

39 Alicja Musiałowa, BPS, KPiSS, 27.03.1957, 14; 31.05.1957, 5; 8.02.1958, 7; Elżbieta Liszka, BPS, KPiSS, 24.11.1959, 23; 10.12.1959, 18.

40 Jadwiga Prawdzicowa, BPS, KPiSS, 5.04.1957, 14; 15.05.1957, 35.

41 SSS II, pos. 18, 20.03.1958, 22, 25.
} 
hasło II zjazdu Ligi Kobiet, „Jak ułatwić życie pracującej kobiecie”, choć zapowiedź zmian była już widoczna. W tym duchu mieściła się również podkreślana przez Prawdzicową konieczność zapewnienia odpowiedniej infrastruktury pozwalającej kobiecie realizować się zawodowo. Przedszkola i żłobki miały wspierać matki w mieście i na wsi zarówno pod względem organizacyjnym, jak i edukacyjno-wychowawczym ${ }^{42}$.

Wybrzmiała także tematyka obecności kobiet na listach wyborczych. W październiku 1957 r. Tatarkówna-Majkowska nawiązywała do wyborów do rad narodowych. Podkreślała „konieczność szerszej reprezentacji kobiet w radach narodowych, [twierdzac, że] i reprezentacja kobiet w Sejmie jest daleko niedostateczna”, o czym miały mówić na spotkaniach $z$ kandydatami same kobiety ${ }^{43}$.

W tematykę tę wpisywała się też praca Regentowej, która na forum sejmu przedstawiła projekt ustawy o zmianie przepisów prawa o aktach stanu cywilnego, regulujący formy zawierania małżeństw. Jego celem była konieczność wprowadzenia przepisów zapobiegających powstawaniu tzw. bigamii faktycznej, która w zdecydowanej większości wiazała się $z$ negatywnymi konsekwencjami dla rodziny, w tym matki i jej małoletnich dzieci. Małżeństwo zawarte tylko w kościele nie powodowało bowiem skutków prawnych, zatem w takiej sytuacji nie miały zastosowania przepisy o wzajemnych prawach i obowiąkach małżonków, w tym kwestie spadkowe, status dzieci pozamałżńskich, prawo do renty rodzinnej czy bigamia. Projekt ustawy zawierał przepis mówiący o tym, „że moc prawną ma tylko zwiazek małżeński zawarty przed urzędnikiem stanu cywilnego, udzielenie zaś ślubu kościelnego może nastapić jedynie po uprzednim zawarciu małżeństwa przed urzędnikiem stanu cywilnego i złożeniu duchownemu wyciagu $z$ aktu małżeństwa" ${ }^{44}$.

Jak zasygnalizowano powyżej, w Sejmie II kadencji była stosunkowo liczna reprezentacja wykształconych i doświadczonych w pracy administracyjnej nauczycielek ${ }^{45}$. Po wojnie był to zawód zdecydowanie sfeminizowany, co częściowo było zapewne konsekwencja niskich upo-

42 SSS II, pos. 8, 11.07.1957, 83; Anna Tarniewicz, pos. 51, 21.12.1960, 143-44; BPS, Komisja Oświaty i Nauki (dalej: KOiN), 2.10.1958, 8.

43 SSS II, pos. 10, 31.10.1957, 22, 25; SSS II, pos. 14, 25.01.1958, 60, 62-63.

44 SSS II, pos. 27, 2.12.1958, 123-26; BPS, Komisja Wymiaru Sprawiedliwości (dalej: KWS), 14.03.1958, 4-5, Wasilkowska, 7-8.

45 Dubiel, Jankiewicz, Krassowska-Jodłowska, Prawdzicowa i Semczuk. Dubiel i Jankiewicz zasiadły w wydziałach oświatowych przy Radach Narodowych, a Krassowska-Jodłowska w latach 1946-1965 była wiceministrem oświaty, a następnie szkolnictwa wyższego. 
sażeń, a tym samym spadku prestiżu zawodu. Uwagę na to zwróciła Semczukowa, postulując konieczność podniesienia poziomu autorytetu nauczyciela w oczach społeczeństwa ${ }^{46}$. Początkowo cztery, a później trzy posłanki zasiadały w Komisji Oświaty i Nauki ${ }^{47}$. Wiosna 1957 r. powołano podkomisję stała do spraw bytu materialnego nauczycieli i poprawy warunków dydaktyczno-wychowawczych, a sam temat w pierwszych latach funkcjonowania sejmu zdominował prace Komisji ${ }^{48}$. W marcu 1958 r. w czasie procedowania planu gospodarczego i ustawy budżetowej Dubiel zwracała uwagę na status i pozycję zawodu nauczyciela, a także na niskie wynagrodzenia w stosunku do poziomu wykształcenia ${ }^{49}$.

Komisja rozpatrzyła projekty ustaw o szkołach wyższych ${ }^{50}$, PAN, akademiach wojskowych oraz o instytutach naukowo-badawczych ${ }^{51}$. Wyznaczyła też nowe pola tematyczne, które w jej opinii wymagały podjęcia prac legislacyjnych. Wskazała na zagadnienia dotyczace opieki nad dzieckiem, także upośledzonym ${ }^{52}$, pracy instytutów naukowo-badawczych, oświaty dorosłych czy wyższych szkół zawodowych ${ }^{53}$.

W pozostałych komisjach posłanki zajmowały się: problematyka przestępczości wśród nieletnich, walka $z$ chuligaństwem ${ }^{54}, \mathrm{w}$ tym pijaństwem $^{55}$, podniesieniem uposażeń dla sędziów i prokuratorów oraz pracowników administracji sądowej, nowelizacją kodeksów postępowania karnego ${ }^{56}$ i administracyjnego ${ }^{57}$, przebiegiem modernizacji przemysłu

46 BPS, KOiN, 23.01.1958, 7.

47 „Sprawozdanie $z$ działalności sejmowej Komisji Oświaty i Nauki w okresie II kadencji Sejmu PRL", (Warszawa : Biuro Sejmu, Wydział Prasowy, 1961).

48 Jadwiga Prawdzicowa, BPS, KOiN, 11.12.1957, 8.

49 SSS II, pos. 21, 27.03.1958, 85-86.

50 Eugenia Krassowska-Jodłowska, BPS, KOiN, 8.01.1959.

51 Eadem, SSS II, pos. 59, 17.02.1961, 29-36.

52 Jadwiga Prawdzicowa, BPS, KOiN, 11.05.1958, 26-27; 20.05.1959, 1-7; 22.05.1959, 1-3; 22.01.1960, 15-16.

53 „Sprawozdanie $z$ działalności sejmowej Komisji Oświaty i Nauki w okresie II kadencji Sejmu PRL", 23.

54 Maria Regentowa, BPS, KWS/KPiSS, 15.10.1959, 1-15; Wasilkowska, BPS, KWS/Komisja Spraw Wewnętrznych (dalej: KSW), 6.11.1957, 13-14.

55 Jadwiga Prawdzicowa, Alicja Musiałowa, Elżbieta Liszka, Maria Regentowa, BPS, KWS / KPiSS, 16.11.1959, 1, 3, 9, 10; 22.10.1959, 2-12, 15, 19, 21-22, 34.

56 Maria Regentowa, „Sprawozdanie z działalności Komisji Wymiaru Sprawiedliwości Sejmu II kadencji", (Warszawa : Biuro Sejmu, Wydział Prasowy, 1961), 12, 15-16; SSS II, pos. 6, 27.04.1957, 525-529; pos. 22, 28.03.1958, 111-123; BPS, KWS, 8.03.1958, 1-7. 57 Zofia Stypułkowska, SSS II, pos. 46, 14.06.1960, 32-37. 
włókienniczego ${ }^{58}$, zagadnieniami reformy budownictwa i nowej polityki mieszkaniowej w zakresie zwiększenia indywidualnej inicjatywy społecznej ${ }^{59}$, w tym przepisów prawa lokalowego ${ }^{60}$, reorganizacja działalności kolegiów karno-administracyjnych ${ }^{61}$, ustawodawstwem dotyczącym powołania $\mathrm{NIK}^{62}$, a także upowszechnianiem kultury w Polsce ${ }^{63}$, również w zakresie realizowanych akcji propagandowych ${ }^{64}$.

\section{Podsumowanie}

Atmosfera, nawet jeśli złudna, demokratyzowania się życia publicznego przed wyborami w 1957 r. nie sprzyjała procesowi zwiększenia uczestnictwa kobiet w parlamencie. W II kadencji Sejmu PRL zasiadło najmniej posłanek, jeśli za okres badawczy przyjmiemy lata 1944/451989. Wpływ na tę sytuację mógł mieć projektowany wzrost stopnia rzeczywistej władzy sejmu, który zbiegł się jednocześnie ze stopniowym wycofywaniem poparcia władz dla idei emancypacji kobiet, silnie propagowanej w latach wcześniejszych. Bardzo liczna była także grupa debiutantek, co wskazuje na odsunięcie na margines życia politycznego „starych” działaczek komunistycznych. Zdecydowaną większość posłanek, co jest naturalne, stanowiły kobiety w wieku średnim. W strukturze wykształcenia parlament powrócił do tradycji sprzed roku 1952 i dominowały posłanki $z$ wykształceniem wyższym lub średnim. Zabrakło licznych w poprzedniej kadencji robotnic i chłopek, na co wpływ mógł mieć powrót do lansowania wzoru kobiety matki. Duża liczba posłanek zwiąana była oczywiście $z$ partyjnymi klubami, liczne było jednak także grono tych bezpartyjnych, $z$ których większość stanowiły debiutantki. Praca na forum sejmu korespondowała $z$ aktywnościa w komisjach parlamentarnych i stanowiła kontynuację zagadnień, które posłanki po-

\footnotetext{
58 Michalina Tatarkówna-Majkowska, „Sprawozdanie z pracy Sejmowej Komisji Przemysłu Lekkiego, Rzemiosła i Spółdzielczości Pracy w okresie II Kadencji”.

59 Zofia Stypułkowska, „Sprawozdanie z pracy Sejmowej Komisji Budownictwa i Gospodarki Komunalnej”, (Warszawa : Biuro Sejmu, Wydział Prasowy, 1961), 11; „Sprawozdanie z pracy Sejmowej Komisji Przemysłu Lekkiego, Rzemiosła i Spółdzielczości Pracy w okresie II Kadencji”, SSS II, pos. 44, 17.02.1960, 303-304.

60 Zofia Stypułkowska, SSS II, pos. 30, 30.01.1959, 40-50.

61 Eadem, SSS II, pos. 27, 2.12.1958, 85-96; BPS, KWS/KSW, 25.10.1957, 2.

62 SSS II, pos. 11, 13.12.1957, 6-21.

${ }_{63}$ Maria Regentowa, SSS II, pos. 35, 12.02.1959, 61-69.

64 Helena Jaworska, SSS II, pos. 49, 2.12.1960, 11, 13-14.
} 
ruszały też w poprzednich kadencjach. Do najważniejszych spraw należały problemy służby zdrowia, polityka oświatowo-wychowawcza, jak również, pomimo trudności, kwestia praktycznego realizowania zasady równouprawnienia płci.

\section{Bibliografia}

\section{Źródła:}

Archiwum Akt Nowych w Warszawie Jaszczukowa, Maria. „Sprawozdania stenograficzne - KRN (SSKRN)”, pos. 9, 29.12.1945-3.01.1946, 273-274.

Kancelaria Rady Państwa w Warszawie

„Sprawozdanie z działalności Komisji Wymiaru Sprawiedliwości Sejmu II kadencji”, (Warszawa : Biuro Sejmu, Wydział Prasowy, 1961).

„Sprawozdanie z działalności sejmowej Komisji Oświaty i Nauki w okresie

II kadencji Sejmu PRL", (Warszawa : Biuro Sejmu, Wydział Prasowy, 1961).

„Sprawozdanie z pracy Sejmowej Komisji Budownictwa i Gospodarki Komunalnej", (Warszawa : Biuro Sejmu, Wydział Prasowy, 1961).

„Sprawozdanie z pracy Sejmowej Komisji Przemysłu Lekkiego, Rzemiosła i Spółdzielczości Pracy w okresie II Kadencji”, (Warszawa : Biuro Sejmu, Wydział Prasowy, 1961).

\section{Opracowania:}

Bardach, Juliusz (red.). Dzieje sejmu polskiego, (Warszawa : Wydawnictwo Sejmowe, 2011). ISBN 978-83-7666-020-2.

Chrobaczyńska-Plucińska, Edyta. „Posłanki w organach ustawodawczych 1944/45-1956. Cechy socjopolityczne i aktywność poselska”, w: Łukasz Tomczak, Katarzyna Zawadzka (red.), Kobiety w wyborach. Wybory kobiet, [w druku].

Chrobaczyńska-Plucińska, Edyta. „Równouprawnienie płci w debacie parlamentarnej Sejmu Ustawodawczego 1947-1952. Zarys problemu”, w: Julita Czernecka, Krystyna Dzwonkowska-Godula (red.), Kobiecość i męskość w publicznym dyskursie, społecznych praktykach $i$ indywidualnych doświadczeniach, Seria wyd. Acta Universitatis Lodziensis. Folia 
Sociologica, nr 70, (Łódź : Wydawnictwo Uniwersytetu Łódzkiego, 2019), 17-38. ISSN 0208-600X

Ćwik, Urszula. „Wybory parlamentarne i wybory do rad narodowych w Polskiej Rzeczpospolitej Ludowej na łamach "Kobiety i Życia» (do 1989 roku)", w: Małgorzata Dajnowicz, Adam Miodowski (red.), Polityka i politycy $w$ prasie XX $i$ XXI wieku, (Białystok : Wydawnictwo Humanica, 2016), 328-337. ISBN 978-83-946177-0-7.

Fidelis, Małgorzata, Jaszczurowska, Maria. Kobiety, komunizm i industrializacja w powojennej Polsce, (Warszawa : Wydawnictwo W.A.B, 2015). ISBN 978-83-280-1532-6.

Fuszara, Małgorzata. Kobiety $w$ polityce, (Warszawa : Wydawnictwo Trio, 2006). ISBN 83-7436-065-8.

Grabowska, Magdalena. Zerwana genealogia. Działalność społeczna i polityczna kobiet po 1945 roku a współczesny polski ruch kobiecy, (Warszawa : Wydawnictwo Naukowe Scholar, 2018). ISBN 978-83-7383-931-1. Janiuk, Jerzy. „Gruźlica w okresie Młodej Polski i dwudziestolecia międzywojennego w teorii i praktyce medycznej (cz. 1)", Medycyna Nowożytna, t. 16, z. 1-2, 2010, 31-81. ISSN 1231-1960.

Jarska, Natalia. „Kobiety w PZPR 1948-1956. Paradoksy mobilizacji politycznej kobiet w stalinizmie”, w: Ewa Chabros, Agnieszka Klarman (red.), Kobiety „na zakręcie” 1933-1989, (Wrocław : Instytut Pamięci Narodowej - Komisja Ścigania Zbrodni przeciwko Narodowi Polskiemu, 2014). ISBN 978-83-61631-40-8.

Jarska, Natalia. „Krótki kurs historii "kobiet». Kobiety w języku partii komunistycznej w Polsce 1945-1989", Polska 1944/45-1989. Studia i Materiały, nr 15, 2017, 241-259. ISSN 2450-8357.

Jarska, Natalia, Perkowski, Piotr. „Droga do władzy? Kobiety w PZPR 19481989”, Pamięć i Sprawiedliwość, nr 27, 2016, 231-246. ISSN 1427-7476.

Mołdawa, Tadeusz. Sejm Polskiej Rzeczpospolitej [!] Ludowej, (Warszawa : Krajowa Agencja Wydawnicza, 1987). ISBN 83-03-01785-3.

Mrozik, Agnieszka. „Poza nawiasem historii (kobiet), czyli po co nam dziś komunistki”, Wakat On-line, nr 3, 2014. ISSN 1896-6950.

Mrozik, Agnieszka. „Wywołać z milczenia. Historia kobiet w PRL-u - kobiety w historii PRL-u", Teksty Drugie : teoria literatury, krytyka, interpretacja, nr 4, 2011, 112-119. ISSN 0867-0633. 
Niewiadomska-Cudak, Małgorzata. Kobiety $w$ polskich organach kolegialnych $w$ latach 1919-2011, (Torun : Wydawnictwo Mado, 2013). ISBN 978-83-62942-33-6.

Ossowski, Piotr. Czerwona Michalina. Michalina Tatarkówna-Majkowska. Prządka-działaczka- łodzianka, (Łódź : Księży Młyn, 2017). ISBN 97883-7729-403-1

Siemieńska, Renata. Płeć, zawód, polityka. Kobiety w życiu publicznym w Polsce, (Warszawa : Uniwersytet Warszawski, Instytut Socjologii, 1990).

Zakrzewska, Janina, Mołdawa, Tadeusz, Ajnenkiel, Andrzej (red.). Historia sejmu polskiego, t. 3: Polska Ludowa, (Warszawa : Państwowe Wydawnictwo Naukowe, 1989). ISBN 83-01-04993-6.

Zielonka, Tadeusz M. „Epidemiologia gruźlicy w Polsce - implikacje w praktyce lekarza rodzinnego", Forum Medycyny Rodzinnej, t. 10, nr 1, 2016, 25-33. ISSN 1897-3590.

Publikacje internetowe:

https://biblioteka.sejm.gov.pl/ 